\title{
State Policy and National Representation: Marijuana Politics in American Federalism
}

\author{
Samuel Trachtman*
}

\begin{abstract}
Members of Congress represent geographically demarcated districts embedded in subnational policy environments. Drawing on policy feedback literature and literature on congressional representation, I argue that, because of this institutional configuration, subnational policy adoption can affect national representation. More specifically, policy reforms in the states they represent can increase pressures members face from organized groups and individuals in their constituencies to promote aligned federal policies. Empirically, I examine the effects of state marijuana legalization. The inferential design leverages differences across the states in statewide citizen initiative institutions, which provides exogenous variation in legalization. Instrumental variables analysis indicates legalization influenced pro-marijuana bill sponsorship and roll calls in the $116^{\text {th }}$ Congress. The evidence points to growing influence of industry in legalizing states - including the ability to mobilize employees and customers - as the key mechanism, thus underscoring the importance of a political economy perspective for studying interdependencies in American federalism.
\end{abstract}

Word count: 9487

\footnotetext{
*Samuel Trachtman (sam.trachtman@berkeley.edu) is PhD Candidate in the Political Science department at University of California, Berkeley. Thanks to Sarah Anzia, Eric Schickler, Alexander Sahn, Chris Warshaw, Chris Witko, Paul Pierson, and David Broockman for helpful comments. Thanks also to Chris Warshaw and Jake Grumbach for sharing data. Any errors are my own.
} 
During his tenure in the Senate (2015-2021), Cory Gardner (R-CO) became a central figure in federal marijuana policy. In 2018, Gardner vowed to block judicial nominees in the Senate until he received a commitment that the federal government would not prosecute marijuana industry (Everett 2018). In the 116th Congress, Gardner sponsored core marijuana-related legislation including the SAFE Banking Act and the STATES Act.

Gardner was not always so pro-marijuana. He opposed Colorado's landmark 2012 ballot initiative legalizing marijuana for adult-use (Birkeland 2019), and there is little in his record prior to 2012 that would indicate he would become an important marijuana proponent. At a basic level, Gardner's pro-marijuana turn appears to be driven by a policy shift in the state he represented. The adoption of adult-use legalization in 2012 led to rapid marijuana industry growth in Colorado, which, as of 2018, took in the most industry revenue per capita of any state. The industry, according to journalist accounts, has gained leverage in Colorado politics, compelling even conservative politicians like Gardner to support industry demands (Fertig 2020; Herndon 2018).

That a policy shift in the state of Colorado might affect the future politics - in this case by shaping the behavior of a member of Congress-accords broadly with the notion of policy feedback, whereby "policy, once enacted, restructures subsequent political processes" (Skocpol 1992, 58). Yet, these dynamics do not fit cleanly within existing policy feedback frameworks for two reasons. First, the policy feedback studies that investigate lawmaking as an outcome tend to rely on broad historical institutional analysis of qualitative data (e.g. Patashnik 2008; Pierson 1994) - not micro-level, quantifiable examinations of lawmaker behavior. While, more recently, the policy feedback literature has taken a micro-level turn, research in this vein has focused on the effects of policies on individual-level behavioral outcomes like turnout and attitudes (see, 
Campbell 2012 for a review), not the behavior of lawmakers. As a result, we have accumulated much quantitative evidence on how policies affect voters, and to a lesser extent, interest groups, but little on how it matters for lawmaking and public policy decisions. The second reason has to do with how policy feedback mechanisms operate within the federal system of American government. Classic studies of policy feedback examine the political implications of national policies, with scholars only more recently turning their attention to the subnational level. Most of this subnational-level work examines the effects of state policies on the politics in the states they were adopted. In this paper, I argue that state policy decisions can also affect how states and districts are represented at the national level.

Broadly speaking, this is because members of Congress represent geographically demarcated units that are embedded in state policy landscapes, and these policy landscapes affect the political pressures that they face. First, state policies structure state economies, and in so doing can affect the ability of organized economic interests to engage in politics and make demands on their representatives. Second, state policies can affect the mobilization and preferences of individual voters, and thereby condition the pressures faced by re-election seeking members. Finally, beyond potentially shaping preferences, state policy enactment might send a signal of constituent preferences that can be difficult for members of Congress to ignore. Put together, these mechanisms suggest the adoption of a policy at the state level can increase the pressure on members of Congress to promote aligned federal policies.

Empirically, I examine marijuana policy reform, a case that provides critical analytical leverage for testing the argument. The wave of state-level legalization over the past two decades has produced great variation in policy landscapes across the states. Moreover, the importance of the statewide citizen initiative - only available in 24 of the states - for passing legalization 
provides exogenous variation that allows for causal estimation of the effect of state policy shifts on representation in Congress.

Does marijuana legalization in the states they represent affect members' behavior in Congress? Studying the 116th Congress, I find evidence that it does. Using whether states permit citizen initiatives as an instrument, I find that members of Congress representing legalizing states were more likely to sponsor or co-sponsor key pro-marijuana pieces of legislation, and also more likely to cast certain pro-marijuana roll-call votes. Bringing quantitative evidence and elite interviews together to investigate mechanisms, I find the most support for the role of growing industry influence in legalizing states, but also find some support for the role of signaling constituent preferences. I find little support for the notion that effects were driven by positive shifts to public favorability wrought by legalization.

Though inability to precisely decompose mechanisms is a limitation, such a decomposition is not critical for the paper's core contributions, which are two-fold. First, this paper provides novel theory and evidence on the ways that the policy terrain affects lawmaking in Congress. Establishing causation using quantitative designs in policy feedback research is notoriously difficult (Campbell 2012). This study is, to my knowledge, the first to leverage a quantitative causal inference design to estimate the effect of prior policy decisions not just on voter behavior or interest group mobilization, but also on the actions of lawmakers in Congress. In doing so, it has the potential to serve as a bridge between work in policy feedback and scholarship on Congress.

Second, this study contributes to a growing body of literature that is fruitfully applying ideas about policy feedback to the study of policy interdependence and diffusion in American federalism. While recent work has illuminated how state policies can "feed into" the interest 
group politics in other states and at the national level (Finger and Hartney 2019; Meckling and Trachtman 2021; Stokes 2020; Trachtman 2020), this study explores how state policy decisions shape the politics in Congress. In doing so, it demonstrates the importance of federalism as an institution that structures policy and political change over time in American politics.

The paper unfolds as follows. First, I develop the core theoretical framework linking state policy decisions to representation in Congress. I proceed to introduce the case- - the politics of marijuana - and the design for estimating the causal effect of state legalization on the behavior of members of Congress. I next present the main empirical results, discuss the evidence on the contributions of different mechanisms, and conclude.

\section{State Policy and Lawmaking in the U.S. Congress}

What determines how members of Congress represent their states and districts? While analyses have highlighted diverse drivers of congressional behavior including ideology (Poole and Daniels 1985) and partisanship (Lee 2009), a consistent finding in the literature is that members represent the preferences of the citizens (Canes-Wrone, Brady, and Cogan 2002) and organized groups (Hall and Wayman 1990) that make up their constituencies.

Individual- and group-level inputs are often taken, in this literature, as exogenous. But these factors, in addition to influencing policy, are also shaped by previously established policy through dynamics of policy feedback. Scholars have identified several mechanisms. Broadly speaking, considering individual behavior, policies both condition the resources that individuals can devote to politics and the way they interpret the role of government in their lives (Pierson 1993). Considering organized interests, policies can incentivize beneficiaries to form citizens groups to advocate for the preservation or expansion of policies (Campbell 2003). Public policies 
can also, by changing the rules governing the economy, increase (or decrease) the political capacities of organized economic interests like firms and unions (Mettler 2014).

If policies can affect the behavior of individuals and the landscape of organized interests, and members of Congress are responsive to the individuals and organized interests that make up their constituencies, we might then expect policy feedback dynamics to ultimately influence the lawmaking process. Indeed, classic historical institutional accounts have traced the full policy feedback cycle, showing how previously adopted policies reshaped the politics, and in doing so, affected the decisions of lawmakers decades later (Hacker 2002; Pierson 1994). The strength of this historical institutional scholarship is the wide lens and attention to macro-level change. However, this also means that it is more limited for generating expectations about how shifts to policy landscapes might affect the decisions of individual lawmakers. And because more microlevel policy feedback work generally focuses on intermediate outcomes at the voter and interest group levels, we have accumulated little quantitative evidence that captures the full policy feedback cycle.

One important exception is Campbell's (2003) analysis of the relationship between Social Security and senior political participation. While Campbell's seminal account is mainly concerned with the individual and group-level feedback effects of Social Security, one chapter investigates outcomes in Congress, thereby completing the "participation-policy cycle" (pg. 124). Campbell shows that, while Democratic members across the board tended to oppose cuts to programs that principally benefit seniors, Republican members' willingness to vote for program cuts depended in part on the number of seniors in their districts. This analysis provides useful evidence but does not provide a clear-cut test of the core hypothesis that the prior adoption of pro-senior policies affected lawmaker behavior in a future political era. The reason is that we 
would expect members representing districts with more seniors to vote for more pro-senior policies even in the absence of prior policy adoption driving seniors' political mobilization. ${ }^{1}$ Ideally, we would be able to compare the behavior of members representing districts in locales featuring pro-senior policies to the behavior of members representing locales without pro-senior policies. But, because programs like Social Security have national scope, there is limited variation to leverage.

This paper relies on state policy variation for empirical leverage. Scholars of policy feedback are increasingly interested in state policy, and broadly speaking, studies have shown that state policies can produce the same sorts of feedback effects on voters (Clinton and Sances 2018; Michener 2018) and interest groups (Anzia and Moe 2016; Feigenbaum, Hertel-Fernandez, and Williamson 2018) as national ones. The approach I take here is somewhat different. Instead of examining policies' political implications in the states where they are passed, I examine the national-level political implications. In particular, I focus on how state policy decisions in the places they represent shape lawmakers' behavior in Congress.

There are several reasons why state policy decisions might affect representation in Congress. The first set of explanations I put forward focus on how state policies structure states' political economies. State policy decisions can influence what sorts of economic activities are profitable, and as a result, which types of firms establish and grow-as well as which fail. And while this paper focuses on firms, the same is true of another set of powerful organized economic interests: labor unions. The ability of unions to develop and maintain organizational strength is heavily

\footnotetext{
${ }^{1}$ And to be clear, Campbell does not frame the analysis as a causal test of the effect of Social Security policy on lawmaking, but rather as part of a broader narrative linking the development of senior programs, greater senior participation, and lawmaking.
} 
influenced by state policies like collective bargaining rules and "right-to-work" laws (Anzia and Moe 2016).

This matters also for politics. The organized interests that develop and grow their economic presence will also have greater political heft (and the opposite for interests that are economically weakened). These interests will therefore be in a stronger position to influence national politics. Moreover, the groups that benefit from, and are strengthened by, state-level policy decisions are likely to also benefit from the adoption of aligned policies at the national level - so might leverage their newfound strength towards that end. One core potential avenue for doing so is putting pressure on members of Congress representing geographic areas where they have a significant presence. It is well-established that members of Congress generally are more responsive to the interests of industries that employ constituents and provide state and local tax revenue in the districts they represent. What is novel here is the understanding that which interests grow and develop a strong presence can be a function of prior state-level policy decisions.

In considering the mechanisms linking state policy to congressional representation, members' re-election motive is a good starting point (Mayhew 1974). Members generally care about their re-election, and firms and unions have demonstrated an ability to transform their economic presence into political power by engaging in elections. Firms mobilizing employees to support their political interests is widespread in contemporary American politics (Hertel-Fernandez 2016). Similarly, mobilizing members in elections is a key source of union political strength (T. Moe 2011). Journalistic accounts and my own elite interviews have highlighted the importance of mobilizing employees (and customers) in the growing political sway of the marijuana 
industry, especially in states that have adopted adult-use (versus just medical-use) legalization (Herndon 2018).

A second reason members might support industries with a presence in their districts draws on the logic of structural power (Lindblom 1977). Because their re-election prospects depend in part on economic performance (Healy and Malhotra 2013), members of Congress have an incentive to support policies that benefit business interests central to economies in the places they represent- even in the absence of active corporate political mobilization. Governors also, for the same reason, might use their sway with members of Congress to advocate for federal laws that align with state policies and programs (Karch and Rose 2019). While marijuana industry's economic contribution remains small relative to major industries like healthcare and energy, it is highly labor intensive and, in many states, growing rapidly (Weed 2020). Moreover, high taxes on marijuana are often used to fund state programs in areas like education and criminal justice, and also to bolster general fund revenues (How do marijuana taxes work? 2020). The importance of industry tax revenue for budgets and programs in the states they represent thus gives members of Congress representing legalizing states another reason to support pro-marijuana federal laws.

In addition to conferring structural power and the ability to mobilize employees or members, state policies that benefit particular organized interests also might provide those interests with a greater capacity to deploy financial resources: lobbying and campaign contributions. Though money is generally ineffective at buying roll-call votes in Congress, research suggests it can shape how members allocate their time and attention. Hall and Wayman's (1990) seminal study, for instance, found that, while PAC contributions from organized interests had no effect on roll call voting, contributions did affect the time that members spent working on issues promoted by contributors - a result that has been corroborated experimentally (Kalla and Broockman 2016). 
Of course, firms and unions can also contribute to the campaigns of members representing districts where they do not have an economic presence. In the marijuana case, as I will show, the industry has mostly targeted members representing legalizing states, but also contributed to campaigns elsewhere. The focus on members representing legalizing states may reflect a strategy of seeking to increase the time and attention that members already inclined to support marijuana reform - perhaps because of other mechanisms associated with industry growth in their districts— spend on the issue.

The mechanisms discussed above focus on organized interests, but public policies also affect individual-level mobilization and attitudes (Campbell 2012). Citizens living in states that adopt reforms - after experiencing them "on the ground"-may become more comfortable with their national adoption. In cases like marijuana where new policies establish new markets and products, consumers can also be a powerful coalition—especially when organized by the firms that sell to them (Culpepper and Thelen 2020).

In considering member responsiveness to shifts in individual-level political behavior, there is ample evidence that members' roll call votes are correlated with the preferences of constituents in their districts (Bartels 1991), and that policy is broadly dynamically responsive to shifts in public attitudes (Erikson, Mackuen, and Stimson 2002). At the same time, more recent findings suggest that member responsiveness might be decreasing. As the major parties have polarized, a greater share of variation in member behavior is explained by partisanship, so a competitive district might be represented very differently depending on the outcome of a close election (Bafumi and Herron 2010). More broadly, studies show that even if member behavior is correlated with voter preferences, there remains a large overall gap between public preferences and public policy (Lax and Phillips 2012). 
One reason is that politicians misperceive the preferences of their constituents. Comparing surveys of state legislators to Cooperative Congressional Election Study data, Broockman and Skovron (2018) find that lawmakers consistently believe the preferences of their constituents are more conservative than they actually are. These biases likely extend to the U.S. Congress. Conducting surveys of senior congressional staffers, Hertel-Fernandez, Mildenberger, and Stokes (2019) find that staffers have skewed perceptions of public attitudes driven, they argue, by a reliance on conservative and business interests for policy information.

This brings us to a final potential mechanism: state policy as signal of constituent preferences. When states adopt particular policies, it provides information to members of Congress representing those states about the preferences of their constituents. This is especially true in cases where state policy is enacted via initiative, which has been a crucial element of liberalizing state marijuana laws. In addition to providing information, these votes can provide political ammunition, giving election opponents the chance to highlight cases where members of Congress are "out-of-step" with their constituents' expressed preferences.

Each of these mechanisms - shifts to interest group resources, shifts in individual-level mobilization, and signals of constituent preferences - are likely to produce positive feedback from state policy to congressional representation. I would therefore expect members to respond to the adoption of policies in the states they represent to be more likely to support aligned policies at the federal level. In the next section, I introduce the empirical context and design for examining this relationship.

\section{State Marijuana Legalization and Representative Behavior}

Marijuana politics has several features that make it particularly suitable for investigating the causal effect of state policy on representation in Congress. First, as I discuss below, the key role 
of the ballot initiative in state legalization of marijuana provides exogenous variation in likelihood of legalization that can be leveraged for causal inference. Second, legalization has produced clear, sizable, and fast changes to states' policy and interest group landscapes: between 2010 and 2020 industry revenue increased by nearly tenfold (Medical \& Recreational Marijuana 2019).

Beyond being a suitable empirical case to examine policy feedback dynamics in Congress, the politics of marijuana is important to understand because of the policy implications. Marijuana prohibition has direct and sizable consequences for people's lives. In 2018, with marijuana already having been legalized for adult-use in 10 states, 40 percent of total drug arrests in the U.S. were for marijuana-related offenses — with a full 92 percent of those arrests just for possession (Gramlich 2020). Convictions for marijuana possession can produce life-altering costs, affecting eligibility for public housing and student financial aid, employment opportunities, child custody determinations, and immigration status among other things (The War on Marijuana in Black and White 2013). For these and other reasons, many advocates see marijuana policy as a crucial piece of broader criminal justice reform (Altieri 2020).

Marijuana policy also has important economic implications. As legalization has advanced, industry revenue has grown steadily from a total of $\$ 3.5$ billion in legal sales in 2014 to over \$13.5 billion in legal sales in 2019 (U.S. Legal Cannabis Market Growth 2019) and marijuana industry is now one of the fastest areas of job growth in the U.S. (Murphy 2019). 


\section{Marijuana Politics and Policy in the U.S.}

Marijuana was first effectively prohibited in the U.S. under federal law by the Marihuana Tax Act of $1937 .^{2}$ The drug's illegality was made official under the Controlled Substances Act of 1970, which, in classifying marijuana as a Schedule 1 drug, prohibited all uses.

Though marijuana remains a Schedule 1 drug at the federal level, in the past 25 years state actions have spearheaded a steady liberalization of marijuana policy. California's Proposition 215 of 1996, which permitted the use of marijuana for medical purposes, initiated a wave of state medical marijuana laws. By the end of 2020, the use of marijuana for medical purposes was legal in 33 states, with another 14 states permitting marijuana with limited THC content for medical use. More recent years have seen the expansion of adult-use marijuana legalization at the state level; between 2012 and the end of 2020, 15 states legalized marijuana for adult use.

The state-level liberalization of marijuana laws has been driven by a combination of increasing public favorability and well-funded advocacy organizations working across the country. Support for marijuana legalization increased from 31 percent of the public in 2000 to 68 percent in 2020 (Brenan 2020). Advocates have taken advantage of favorable public opinion by relying heavily on citizen initiatives, and organizations like Marijuana Policy Project (MPP) have developed expertise in running initiative campaigns.

Even as the legal landscape of marijuana has shifted dramatically at the state level, federal law has remained largely stagnant. Lack of progress at the federal level has led to growing conflict between state and federal laws, leaving the burgeoning industry in a highly fragmented legal environment. Most notable is uncertainty over enforcement of federal laws prohibiting

\footnotetext{
${ }^{2}$ Rather than outright prohibition, the Marijuana Tax Act imposed steep excise taxes on all marijuana sales, deterring production and consumption (in that era the authority to regulate medicines was reserved for the states).
} 
marijuana (Higdon 2019). But in addition, federal prohibition limits industry access to banking and other financial services and limits small businesses' access to tax deductions.

Warming public attitudes, industry growth, and growing costs from state-federal policy conflicts have produced momentum for reform in Congress. Several pro-marijuana bills were introduced in the 115th Congress, but Republican majorities kept them from being brought to floor votes. With various forms of legalization continuing to spread across the states, and Democrats taking control of the House in 2018 elections, advocates and industry interests saw the 116th Congress as a crucial opportunity to advance reform at the federal level. As one journalist wrote: "This is the first Congress in history where, going into it, it seems that broad marijuana reforms are actually achievable" (Higdon 2019).

Efforts from advocates and industry coalesced around three broad goals— - each with a related proposed bill—in the 116th Congress. First, and narrowest in scope of the three, was providing the marijuana industry with greater access to banking services. The proposed SAFE Banking Act would "create protections for depository institutions that provide financial services to cannabisrelated legitimate businesses and service providers for such businesses" (Perlmutter 2019). The second major goal was broadly protecting industry and consumers in states that have legalized marijuana from federal interference or prosecution. The STATES Act would exempt individuals and corporations operating legally according to state law from federal enforcement. The third and broadest goal was amending the Controlled Substances Act to end federal prohibition on marijuana. The MORE Act would both end federal prohibition as well as expunge prior convictions. Notably, support for the MORE Act comes to a greater extent from advocates than from industry interests, which have focused on narrower bills. ${ }^{3}$

\footnotetext{
${ }^{3}$ Interview with marijuana policy advocate, 5/13/2020.
} 


\section{Instrumental Variables Design}

Even using state policy variation for leverage, causally estimating the feedback effects of prior policies on the actions of lawmakers poses inferential problems. Since policy adoption is nonrandom, any observed relationship between subnational policy and member behavior might be driven simply by a correlation in the preferences of subnational policymakers and members of Congress - not by the theoretical mechanisms discussed above. In this case, the types of states that legalize marijuana are also likely to be the types of states that elect representatives that are more progressive on marijuana policy, making it difficult to estimate the effect of legalization on representation in Congress.

This paper relies primarily on an instrumental variables (IV) design for causal inference. The IV design draws specifically on the fact that citizen initiatives have been a fundamental tool for legalization advocates. The first 8 states to legalize marijuana for adult-use did so via citizen initiative. For pro-marijuana organizations, whether states allowed initiatives has been a major factor in determining where to allocate time and resources. The importance of the initiative, according to one advocate, stems from the fact that the public generally holds more liberal views on marijuana than representatives in state legislatures. ${ }^{4}$ As of the end of 2020, whether a state allowed citizen initiatives was highly correlated with whether it permitted marijuana for adult use $(\rho=.51)$ and whether it allowed medical marijuana $(\rho=.44)$ - the first requirement for a valid instrument.

To serve as a valid instrument, initiative status (whether they are allowed to enact statutes or constitutional amendments) must also, conditional on observables, only be associated with member behavior through the mechanism of legalization (the "exclusion restriction"). There is

\footnotetext{
${ }^{4}$ Interview with Marijuana Policy Project (MPP) senior official, April 2019.
} 
good reason to think this is the case. Initiative processes were generally put into place around the turn of the 20th century in response to pressure from elements of the Progressive movementlong before marijuana policy was a salient issue. (Appendix A.1 provides each state's initiative rules.) If initiative status were related to congressional representation on marijuana issues through mechanisms other than legalization, then we would expect these rules to also be related with factors generally associated with the behavior of members of Congress. But, as indicated by Figure 1, whether a state allows citizen initiatives is unrelated to the factors political scientists generally believe to drive congressional behavior. First, initiative status is uncorrelated with measures of congressional ideology in the 116th Congress. In addition, it is slightly negatively correlated with 2016 Democratic presidential vote share, which should bias results downwards to the degree it is not accounted for in analysis. Finally, it is neither correlated with state-level measures of attitudes towards marijuana legalization nor state-level measures of social liberalism in the mass public from 2000 to 2010 (Caughey and Warshaw 2016, 2018). ${ }^{5}$

\footnotetext{
${ }^{5}$ Measures are derived from aggregating policy questions across polls using a group-level itemresponse model.
} 
Figure 1: Whether states allow citizen initiatives is correlated with marijuana legalization and uncorrelated with factors generally associated with congressional behavior. Points represent bivariate association between whether a state allows citizen initiatives and each outcome. Outcome are standardized to a 0-1 scale. 95 percent confidence intervals are calculated using standard errors clustered at the state level.

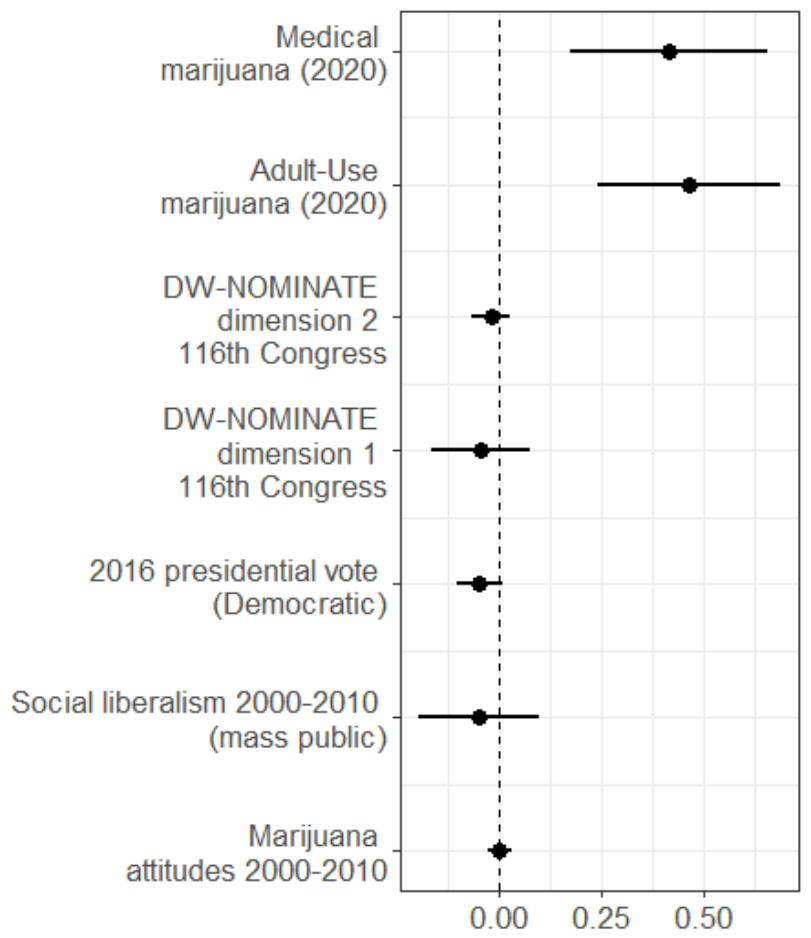

\section{The Effect of State Marijuana Legalization on Bill Sponsorship and Roll Calls}

I now turn to examining the effects of legalization on bill sponsorship and roll calls in the $116^{\text {th }}$ Congress, ${ }^{6}$ starting with bill sponsorship since there is more data (many more bills have been introduced than have been voted on). I focus on the three bills discussed above at the core of the industry and advocacy groups' agenda: the SAFE Banking act; the STATES Act; and the MORE Act. Figure 2 demonstrates that members of Congress representing states with more

\footnotetext{
${ }^{6}$ This was the first since the initiation of the state-level adult-use legalization wave in 2012 in which advocates and industry interests perceived an opportunity for significant legislative progress.
} 
liberal marijuana laws were descriptively more likely to sponsor liberal marijuana legislation, but this association does not provide evidence of a causal effect.

Figure 2: Bill sponsorship by state legalization status. Bars represent proportion of members sponsoring or co-sponsoring each bill. Blue bars are Democrats, and red bars are Republicans.

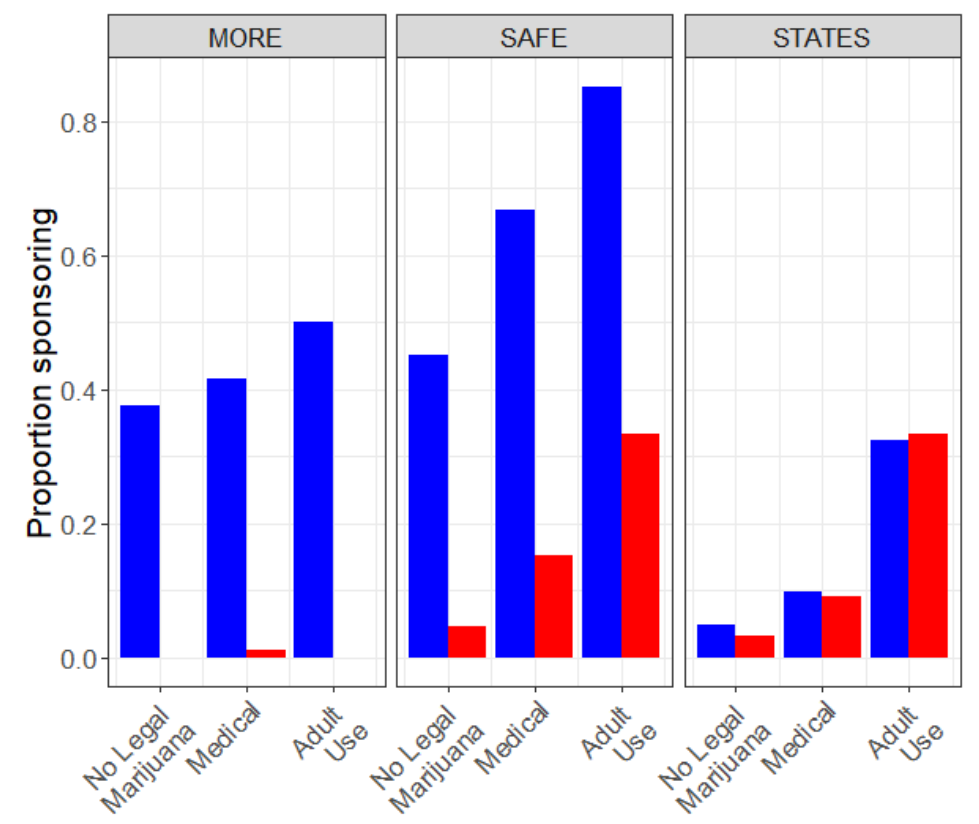

Analysis using citizen initiative rules as an instrument, though, as discussed above, can provide causal leverage. The key treatment is a measure of state marijuana legalization status at the end of the 116th Congress. ${ }^{7}$ In the main analysis, I code the treatment variable as 0 for states with neither medical nor adult-use, 1 for states with medical marijuana, and 2 for states with adult-use legalization. ${ }^{8}$ Treatment is instrumented by whether a state allows citizen initiatives as

${ }^{7}$ Status at the end of the Congress is used since a shift in legalization occurring in the middle of the Congress could plausibly affect member behavior for the remainder.

${ }^{8}$ Since citizen initiatives predict both medical and adult-use legalization, the IV analysis cannot parse their separate effects. In addition, there remains significant policy variation within the categories of medical-use and adult-use. For instance, states vary on the availability of licenses for cultivation and distribution. Measurement error in the treatment should attenuate estimates, making it more difficult to detect effects. Results are robust to coding only adult-use states as "treated" (see appendix, A.2). 
discussed above. For outcomes, first, I record binary measures of whether members sponsored or co-sponsored each of the SAFE Banking Act, STATES Act, and MORE Act. I also estimate a broader marijuana bill sponsorship score by computing the proportion of the 14 priority pieces of legislation promoted by the industry group National Cannabis Industry Association (NCIA) sponsored or co-sponsored by each member. (The distribution of the bill sponsorship score by party and legalization status is provided in the Appendix A.1.)

Two-stage least squares regression is used to estimate the effect of liberalization of state-level marijuana law on these outcomes. The first stage predicts adult-use marijuana legalization from the ballot initiatives variable. First stage results presented in the appendix (A.2) demonstrate that citizen initiative rules are a strong instrument for legalization. The second stage estimates the relationship between predicted legalization and bill sponsorship. ${ }^{9}$ I estimate models both with and without state- and member-level covariates: party-identification (PID), ideology (DWNOMINATE); and state-level covariates: 2016 Democratic presidential vote share; and social liberalism of the mass public.

Estimates are presented in Figure 3. For the SAFE Banking Act and the STATES Act, I estimate that state-level marijuana legalization increased the likelihood that members (representing those states) sponsored liberal marijuana bills. The non-covariate adjusted coefficient of .24 for the SAFE Banking Act, for instance, indicates a 1-point shift in legalization status (from prohibition to medical, or medical to adult-use) is associated with an increase of 24 percentage points $(\mathrm{SD}=.50)$ in likelihood that members sponsored the Act. I estimate effects of similar magnitude for the STATES Act. I do not estimate a statistically significant effect for the MORE Act, which may be driven by the fact that sponsorship of this bill was more partisan than

\footnotetext{
${ }^{9}$ Analysis uses the ivreg function in the AER package in $\mathrm{R}$.
} 
the others (see Figure 2). Turning to members' broader bill sponsorship scores, I find evidence of a causal relationship. The coefficient of .06 suggests that a 1-point shift in legalization status is associated with an increase of $.06(\mathrm{SD}=.11)$, which corresponds to .84 additional NCIAsupported bills sponsored on average.

Figure 3: Effects of state marijuana legalization on bill sponsorship in the 116th Congress. Estimates are derived from two-stage least squares regression. State legalization status is instrumented by citizen initiatives rules. 95 percent confidence intervals are calculated using standard errors clustered at the state-level.

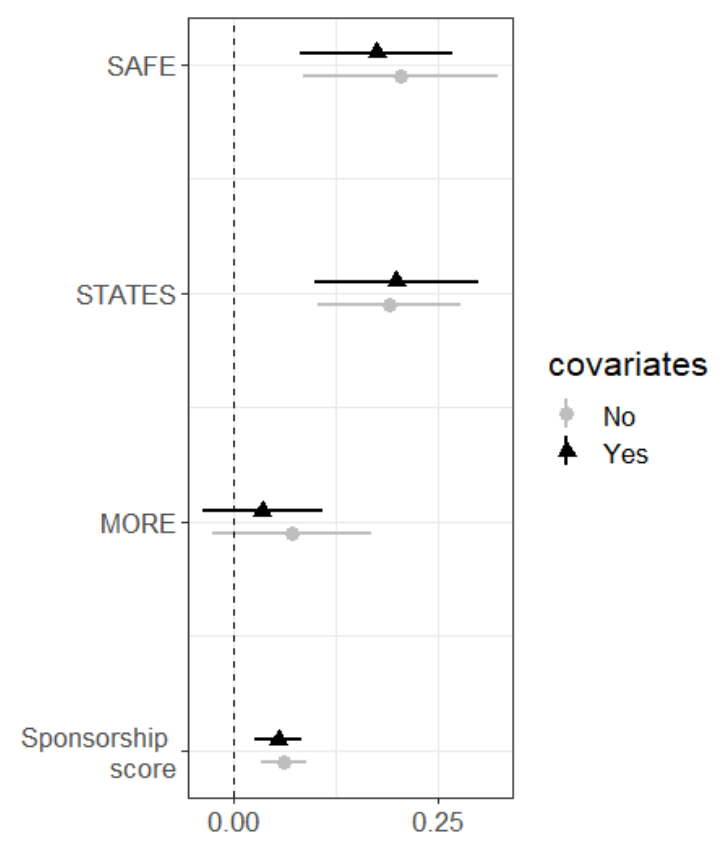

Of course, the validity of these results depends on the exclusion restriction. One concern is that ballot initiative processes are somewhat more common in the western part of the country, an area that is also potentially ideologically more pro-marijuana. But, as I demonstrate in the appendix (A.2), results are generally consistent (though with reduced precision) when excluding western states from the analysis.

That said, there remains the concern that there is some unobservable underlying difference between initiative and non-initiative states driving the findings. But if the association between ballot initiative rules and marijuana bill sponsorship were driven by mechanisms unrelated to 
state-level legalization, we would expect an association between initiative rules and congressional behavior on marijuana prior to the current era of legalization. Here, I present a falsification test demonstrating that this is not the case. Specifically, I investigate which members sponsored a series of bills introduced in the 1980's that would have rescheduled marijuana to Schedule II, thereby allowing doctors to prescribe the drug to patients in need (subsequently referred to as "rescheduling bills"). The first in the series of rescheduling bills, HR 4498, was introduced in the 97th Congress (in 1981) and co-sponsored by a bipartisan group of 84 members. Similar pieces of legislation were introduced in the $98^{\text {th }}$ and $99^{\text {th }}$ Congresses (HR 2292 and HR 2232 respectively).

Figure 4: Reduced form relationship between citizen initiatives and bill sponsorship preand post-legalization wave. Left panel presents reduced-form relationship between citizen initiatives and sponsorship of rescheduling bills prior to legalization wave. Right panel presents reduced-form relationship for the 116th Congress. 95 percent confidence intervals calculated using standard errors clustered at the state-level.
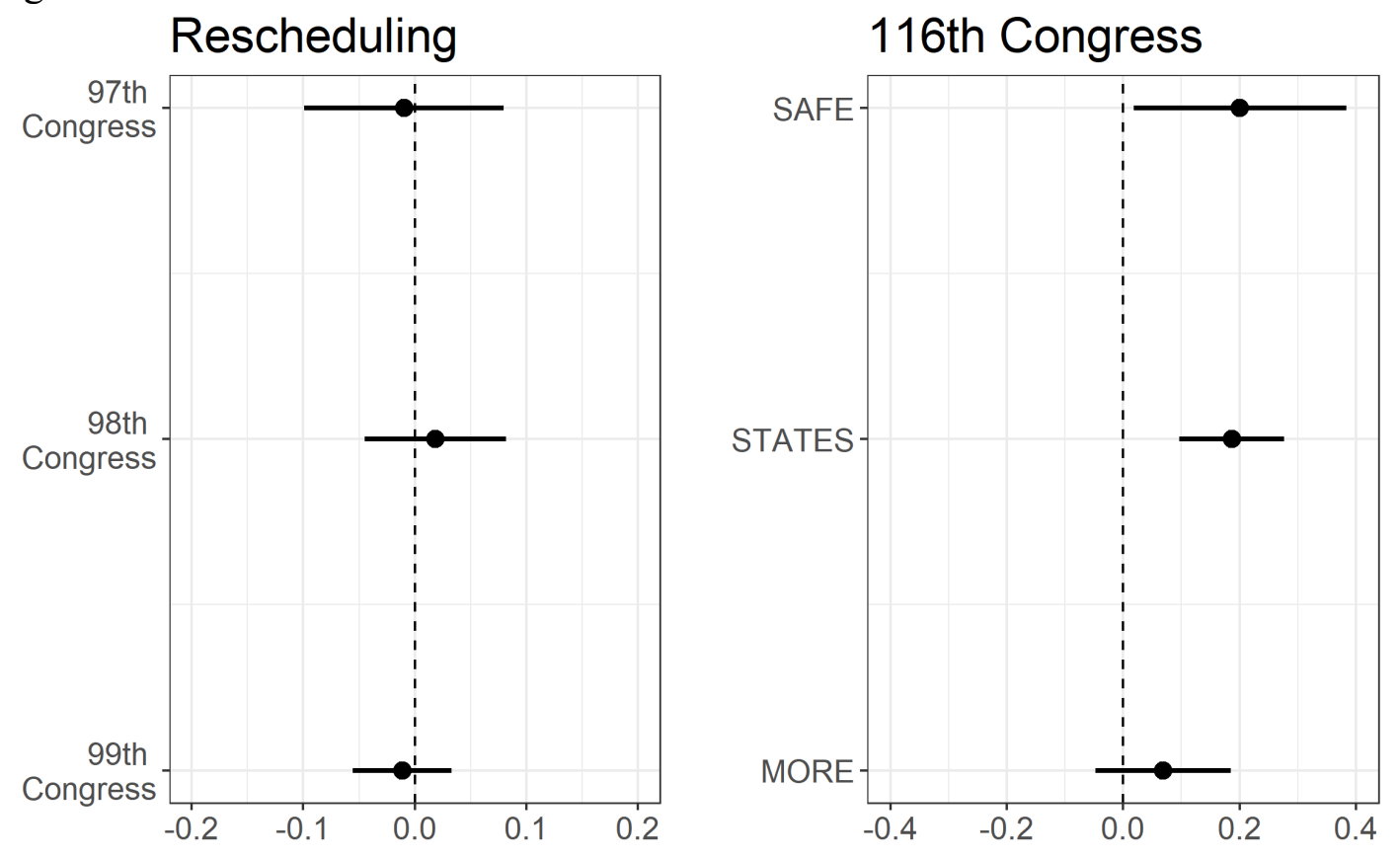

Figure 4 demonstrates no correlation between initiative rules and bill sponsorship in the 97th through 99th Congresses. On the other hand, the right panel of Figure 4 presents a positive 
reduced-form relationship between initiative rules and sponsorship of the SAFE Banking Act and the STATES Act in the 116th Congress. This test therefore provides support for the exclusion restriction assumption necessary for a causal interpretation of the IV analysis. ${ }^{10}$

I now turn to an investigation of the effect of the liberalization of state marijuana laws on members' roll-call votes on marijuana issues. This analysis is necessarily more restricted than the analysis of bill sponsorship since few roll calls have been taken. In June 2019 and July 2020, the House passed amendments (267-165 and 254-163 respectively) that would prevent the Department of Justice (DOJ) from using funds to prosecute marijuana offenses in jurisdictions where it is legal; ${ }^{11}$ in September 2019 the House passed the SAFE Banking Act 321-103; and in December 2020 the House passed the MORE Act 228-164. ${ }^{12}$

The IV analysis of roll calls has a similar structure as the bill sponsorship analysis, except the main outcome is a binary indicator for whether members supported the legislation (versus sponsored). Results, presented in Figure 5, indicate that legalization did affect whether members voted for budget amendments to restrict the DOJ. The covariate-adjusted coefficient estimates of .09 for the 2020 version and .07 in 2019 indicate that a 1-point shift in legalization status (from prohibition to medical, or medical to adult-use) is associated with an increase of 7 and 9 percentage points, respectively, in likelihood of votes in favor. Interestingly, though results

${ }^{10}$ As an additional check, I also conduct the main analyses using regression adjustment for identification versus the instrumental variables method. This approach does not rely on the exclusion restriction assumption, but instead assumes that congressional members representing legalizing and non-legalizing states are otherwise comparable conditional on measures of ideology, party identification, state-level Democratic vote share in the 2016 Presidential election, and estimated state-level ideology. As shown in the appendix (A.2), this approach yields similar estimates as the instrumental variables approach.

${ }^{11}$ Since these amendments are part of the federal budget, they must be renewed every year.

${ }^{12}$ The Senate has not voted on any of these bills. 
presented above indicate that legalization affected whether members sponsored the SAFE

Banking Act, I do not find that legalization had a statistically significant effect on roll call voting for this bill. I also estimate a null result for the MORE Act, which was for the most part a partyline vote (only 6 Democrats voted against, and only 5 Republicans in favor). ${ }^{13}$

Figure 5: IV estimates of the effect of state marijuana legalization on roll calls in $116^{\text {th }}$ Congress. Estimates are derived from two-stage least squares regression. State legalization status is instrumented by citizen initiatives rules. 95 percent confidence intervals are calculated using standard errors clustered at the state-level.

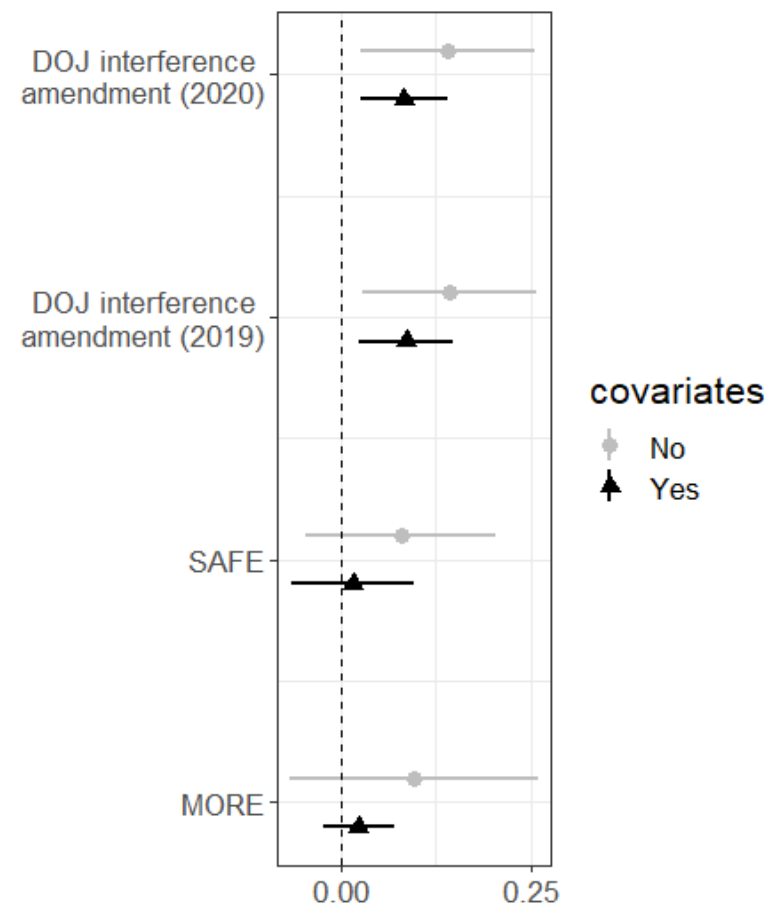

Overall, the evidence on roll-call voting is mixed. That said, the stronger estimated effects of state legalization on bill sponsorship compared to roll-call voting is consistent with the mechanism of industry influence: interest groups are generally more adept at shaping members' attention than their highly visible roll-call votes (Hall and Wayman 1990). Indeed, statistically

${ }^{13}$ Results are robust to a specification that uses covariate-adjustment for inference instead of the IV design — see the appendix (A.2). 
significant findings on roll calls were observed only for the DOJ amendments, which were somewhat lower-profile votes.

\section{Investigating Mechanisms}

In developing the paper's theoretical argument, I proposed that state policy might affect representation in Congress by, first, shaping the political economy in ways that influence the pressures faced by reelection-seeking members; and second, by sending signals that provide information about constituent preferences. While providing a precise decomposition of the role of these potential mechanisms in the empirical case is not possible with the available data, in this section I bring together quantitative and qualitative evidence to provide some insight as to how these mechanisms have contributed to the overall effect observed. As part of gathering qualitative data, I conducted 8 semi-structured elite interviews with individuals working in marijuana politics and policy.

In considering how state legalization affected the pressures faced by members of Congress, it is worth considering, first, the extent to which legalization has actually affected organized economic interests. The answer is: quite a lot, especially in states adopting adult-use legalization. According to NCIA, as of 2018 the average state with medical marijuana featured sales of $\$ 21$ per capita (an average of 100 million dollars in total revenue), while the average state with adultuse legalization featured sales of $\$ 130$ per capita (an average of over a billion dollars in revenue). ${ }^{14}$

Revenue growth in legalizing states has increased the capacity of industry interests to engage politically at the national level. To examine exercise of instrumental power, I draw on lobbying and campaign contributions data collected by the Center for Responsive Politics. The data reveal

\footnotetext{
${ }^{14}$ Public data for other years is not yet available.
} 
a sharp increase in lobbying from marijuana industry coinciding with recent state adoption of adult-use legalization. Annual federal lobbying from the marijuana industry has grown from just 45,000 dollars in 2012 - the year that Colorado and Washington voters legalized marijuana for recreational use by ballot initiative - to nearly 6 million dollars in 2019 ("Marijuana Lobbying Profile" n.d.). Campaign contributions data also suggest that legalization has affected the political presence of marijuana industry. Firms in the industry did not donate to congressional campaigns prior to the 2018 cycle. In the 2018 cycle, however, marijuana industry interests contributed in 19 percent of House races in states with adult-use marijuana, and just 2 percent of House races elsewhere. Discrepancies for the Senate were less stark, with contributions in 7 percent of races with adult-use marijuana, and 5 percent of races elsewhere. IV analysis again using citizen initiative rules to instrument for legalization suggests this relationship is causal (see appendix A.3).

In addition to leveraging its growing resources for lobbying and campaign contributions, the marijuana industry has leveraged its economic growth to engage politically by mobilizing consumers and employees. For instance, in Colorado, Governor Jared Polis collaborated with industry interests to turn out marijuana consumers and industry employees in his 2018 reelection. As part of this effort, the campaign matched the state's database of marijuana employees to the voter file to identify potential supporters, and then sent them targeted text messages and mailers (Frank 2018). The sway of marijuana industry and marijuana voters in Polis's 2018 bid was a major reason why former Senator Cory Gardner, who anticipated a tough re-election in 2020 (which he ultimately lost), made marijuana such a priority in the $116^{\text {th }}$ Congress. ${ }^{15}$

${ }^{15}$ Interview with marijuana advocate 12/21/2020; interview with marijuana lobbyist 11/4/2020. 
Outside of industry mobilization, another potential mechanism is that state legalization leads the broader public in legalizing states to be more liberal on marijuana, which then drives members of Congress to respond by supporting marijuana reform. To investigate the association between marijuana legalization and public attitudes, I use state-level estimates of support for marijuana legalization collected by Caughey and Warshaw (2020). ${ }^{16}$ Using a difference-indifferences design, I compare changes to public opinion in legalizing states to changes in public opinion over the same time period in a set of similar non-legalizing states. More specifically, I leverage a method recently developed by Xu (2017), which is particularly useful since it allows for implementation of synthetic controls in cases of multiple treated units and variable treatment periods. The method uses a linear interactive fixed effects model to impute counterfactuals for each treated unit (states legalizing marijuana). I consider legalization of marijuana for medical use and for adult use separately.

${ }^{16}$ Estimates are weighted based on raked state-level weights using race, education, gender, and age. I use weighted estimates instead of estimates from multilevel regression and poststratification (MRP) since smoothing from MRP might make it more difficult to detect treatment effects (Caughey and Warshaw 2019; Lewis and Linzer 2005). 
Figure 6: Marijuana legalization is not associated with changes to state-level public opinion. Solid lines represent average support for marijuana legalization in legalizing states. Dashed line represents average support in comparable non-legalizing states.

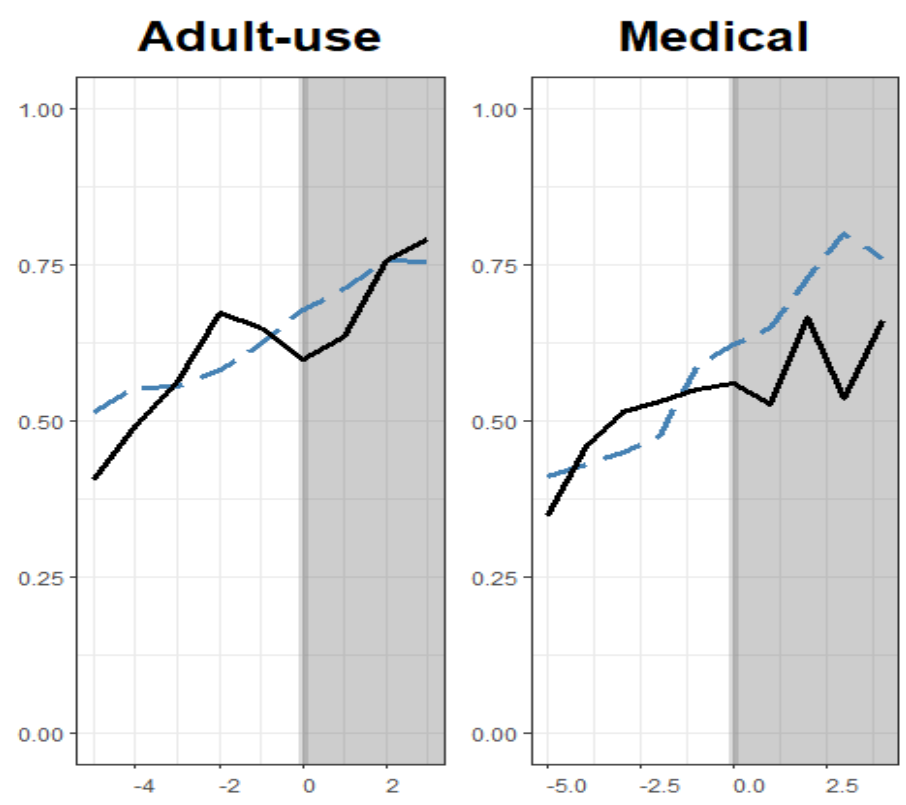

Figure 6 plots average support for marijuana legalization over time for both the treated states and the synthetic controls. In addition to estimates of state-level support for legalization, the model also includes estimates of mass ideology (cultural and economic dimensions) (Caughey and Warshaw 2020). If legalization led to greater public support for marijuana, we would expect the solid series representing legalizing states to jump above the dashed series at treatment (year 0 in Figure 6). The evidence, though, suggests no such effect. Indeed, public opinion, for both adult-use and medical, is slightly more favorable in the synthetic control group, though not statistically distinguishable from the treated group. This suggests that state-level legalization has not disproportionately improved public opinion in the states where it is adopted. ${ }^{17}$

\footnotetext{
${ }^{17}$ State legalization may well have improved public opinion across all states, but if this were the case, it would not be expected to differentially affect members of Congress representing legalizing versus non-legalizing states.
} 
However, even if it did not drive improved public opinion, it is likely that marijuana legalization —especially in the majority of cases when it was enacted via ballot initiativeprovided a signal of public favorability to lawmakers in Congress. This is the mechanism that, along with growing influence of industry in legalizing states, interviewees working as lobbyists and policy advocates were most likely to raise. It is difficult to investigate quantitatively, though. One analysis that can provide insight into the importance of this mechanism is exploring the relationship between the length of time since legalization and representation. If signaling were driving the effect of legalization on representation, we would expect members representing states with more recent (and thus more salient) legalization votes to adopt more pro-marijuana positions. If industry influence were more fundamental, we would expect members representing states that legalized further in the past, and where industry had a greater amount of time to develop, to adopt more pro-marijuana positions.

Figure 7 presents models with members' bill sponsorship scores (recall, this is the proportion of the bills promoted by the NCIA sponsored by the member) and roll calls on the votes for which a positive effect of legalization was estimated as outcomes, and the number of years of legalization for a members' home state as the key independent variables. The left panel presents results for adult-use states and the right panel presents results for medical-use states (without adult-use). Broadly speaking, results lend support for the industry influence mechanism — not signaling. For adult-use states, in both bivariate and covariate-adjusted models, years since legalization is positively and statistically significantly associated with both bill sponsorship and roll-call outcomes. I recover similar results in the bivariate models of medical-use legalization, but they are not robust to covariate adjustment. This may reflect the adult-use legalization tends to have a much greater effect on industry growth than medical-use legalization. 
Figure 7: Years since legalization is associated with pro-marijuana bill sponsorship and roll calls. Points represent OLS coefficient estimates on variable recording years since legalization, with bill sponsorship and roll-call votes as outcomes. Lines are 95 percent confidence intervals computed using standard errors clustered at the state level.

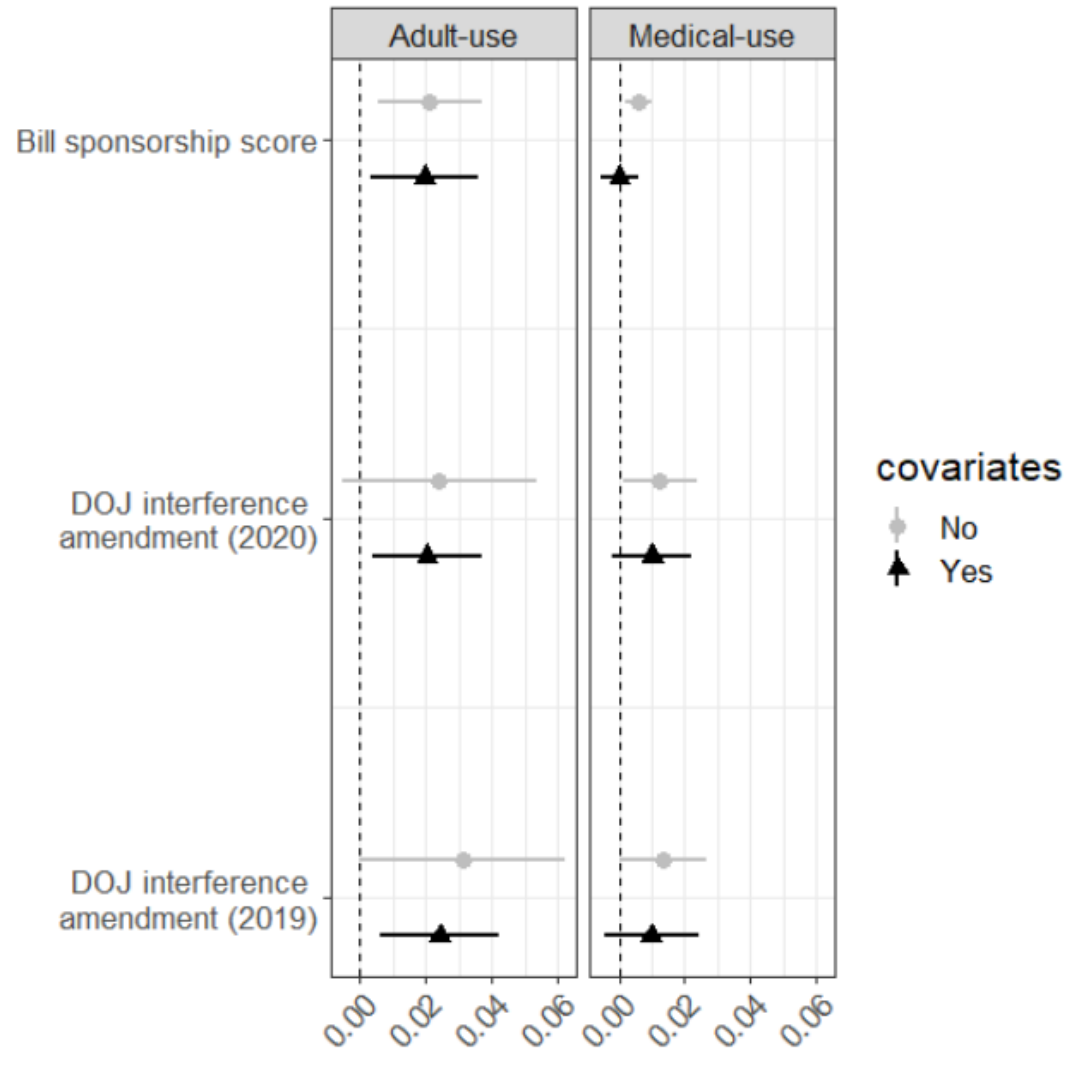

To be sure, this analysis does not rule out the signaling mechanism, and the fact that this mechanism was mentioned by several interviewees working in marijuana politics suggests this would be an incorrect conclusion. Rather, it suggests that in comparing the mechanisms of signaling to industry influence, growing industry influence is likely playing a greater role in mediating the relationship between state marijuana legalization and national representation in Congress.

\section{Discussion}

Using an IV design that leverages exogenous variation in marijuana legalization from longstanding differences in the availability of citizen initiatives, I have shown that the policy 
landscapes in the states they represent affect the behavior of members of Congress. I observed strongest effects for bill sponsorship, but also effects on certain lower-profile roll-call votes. The evidence suggests the strongest mechanism driving these effects is growing industry influence in legalizing states, though other mechanisms - particularly signaling of public preferencescannot be ruled out.

The set of analyses is not without its limitations. One limitation is a short temporal window. Since adult-use legalization and the emergence of the marijuana industry are relatively new phenomena, data is limited. For instance, only a few roll-call votes related to marijuana legislation have been taken since the state legalization wave began. As more data become available, researchers will be able to extend the analyses performed here. In addition, while this study indicates a causal link between state-level adult-use legalization and representation in Congress, there remains uncertainty with respect to the mechanisms. Finally, it should be noted that these analyses likely underestimate the full effects of state legalization on the politics in Congress. While this paper demonstrates the effect of legalization on members representing legalizing states relative to non-legalizing states, mechanisms like growing industry presence in Congress are likely to affect legislators across the country — they are simply more pronounced in legalizing states.

Future empirical work can build on the theoretical framework developed here to explore the role of different mechanisms in different policy cases. For instance, the role of signaling is likely unusually important in this case due to the role of the ballot initiative compared to cases where state policy reform is achieved via legislation. The findings on the role of state policy in structuring state political economies and, as a result, the pressures faced by members is likely to be more broadly generalizable to other policy areas. 
Consider, for instance, climate change. Industries reliant on the burning of fossil fuels are enormously powerful in American politics, spending vast amounts of money on lobbying and campaign contributions in federal (Brulle 2018) as well as state and local politics (Stokes 2020). Organized interests enriched by the extraction and burning of fossil fuels have also become a key organizing force within the Republican Party (Skocpol 2013). The power of these groups in our politics is built atop a set of policies in place across the federal system that not only fail to adequately price the negative externalities of burning fossil fuels (Metcalf 2019), but also subsidize the production of fossil fuels (Fossil Fuel Subsidies: A Closer Look at Tax Breaks and Societal Costs 2019). But as states governments continue to adopt and strengthen policies driving the transition to renewable energy (Rabe 2004), this is likely to reshape the pressures faced by members of Congress, potentially opening new opportunities for federal policy.

Or consider policing. The killing of George Floyd in May 2020 led to widespread protests calling for actions across levels of government to enact major policing reforms, including in Congress (Ferris, Caygle, and Bresnahan 2020). Though these reforms are widely popular (Newell 2020), a major impediment to their enactment is the power of police unions, which leverage financial resources and ability to mobilize members to prevent reforms (Broadwater and Edmondson 2020). Analysis drawing on the framework proposed here might explore the degree to which the power of police unions to prevent reform in Congress is bolstered by pro-police state and local policies.

One key scope condition for this mechanism is the degree to which policy areas feature strong vested interests dependent on material benefits from government policies (T. M. Moe 2015). Considering the role of state and local policy in congressional representation, another key scope condition is the degree to which governance is shared between federal, state, and local levels-a 
core feature of American federalism (Grodzins 1982). The scope of subnational authority in American federalism and increasingly active role of state governments in American politics (Franko and Witko 2018; Grumbach 2018) means it is crucial that we develop a better understanding of the implications of state policies for the broader polity.

The potential applicability of the interest group mechanism identified in this paper across policy domains also has implications for fundamental models of lawmaking in American politics. Standard models conceive of lawmakers as primarily driven by the preferences of the median voters in their districts, which are generally taken as exogenous (Downs 1957). Alternative perspectives suggest that lawmakers are primarily responsive to the pressures of organized interests seeking to advance policy goals, and moreover, that the ability of competing groups to influence politics is structured by the existing policy-scape (Hacker and Pierson 2014). Findings presented here support the notion that existing policy, in part by shaping interest group capacities, affects congressional representation. This paper therefore provides quantitative empirical grounding for the difficult-to-test arguments in favor of the policy-focused approachand one empirical framework for scholars working in this vein.

\section{References}

Altieri, Erik. 2020. "Marijuana Legalization and the Fight for Racial Justice." NORML. https://norml.org/blog/2020/06/01/marijuana-legalization-and-the-fight-for-racialjustice/ (June 30, 2020).

Anzia, Sarah F., and Terry M. Moe. 2016. "Do Politicians Use Policy to Make Politics? The Case of Public-Sector Labor Laws." American Political Science Review 110(4): 763-77.

Bafumi, Joseph, and Michael C. Herron. 2010. "Leapfrog Representation and Extremism: A Study of American Voters and Their Members in Congress." American Political Science Review 104(3): 519-42.

Bartels, Larry M. 1991. “Constituency Opinion and Congressional Policy Making: The Reagan Defense Buildup." American Political Science Review 85(2): 457-74. 
Brenan, Megan. 2020. "Support for Legal Marijuana Inches Up to New High of 68\%." Gallup. https://news.gallup.com/poll/323582/support-legal-marijuana-inches-new-high.aspx (February 12, 2021).

Broadwater, Luke, and Catie Edmondson. 2020. "Police Groups Wield Strong Influence in Congress, Resisting the Strictest Reforms." The New York Times. https://www.nytimes.com/2020/06/25/us/politics/police-reforms-congress.html (July 8, 2020).

Broockman, David E., and Christopher Skovron. 2018. "Bias in Perceptions of Public Opinion among Political Elites.” American Political Science Review 112(3): 542-63.

Brulle, Robert J. 2018. "The Climate Lobby: A Sectoral Analysis of Lobbying Spending on Climate Change in the USA, 2000 to 2016." Climatic Change 149(3): 289-303.

Campbell, Andrea Louise. 2003. How Policies Make Citizens: Senior Political Activism and the American Welfare State. Princeton University Press.

___ 2012. "Policy Makes Mass Politics." Annual Review of Political Science 15(1): 33351.

Canes-Wrone, Brandice, David W. Brady, and John F. Cogan. 2002. "Out of Step, out of Office: Electoral Accountability and House Members' Voting." The American Political Science Review 96(1): 127-40.

Caughey, Devin, and Christopher Warshaw. 2020. Dynamic Democracy: Citizens, Politicians, and Policymaking in the American States, 1936-2018. Chicago: University of Chicago Press.

Clinton, Joshua D., and Michael W. Sances. 2018. "The Politics of Policy: The Initial Mass Political Effects of Medicaid Expansion in the States." American Political Science Review 112(1): 167-85.

Culpepper, Pepper D., and Kathleen Thelen. 2020. "Are We All Amazon Primed? Consumers and the Politics of Platform Power." Comparative Political Studies 53(2): 288-318.

Downs, Anthony. 1957. "An Economic Theory of Political Action in a Democracy." Journal of Political Economy 65(2): 135-50.

Erikson, Robert S., Michael B. Mackuen, and James A. Stimson. 2002. The Macro Polity. Cambridge University Press.

Everett, Burgess. 2018. “Colo. Senator: Trump Easing up on Pot Crackdown.” POLITICO. https://politi.co/2v7LQ80 (July 7, 2020).

Feigenbaum, James, Alexander Hertel-Fernandez, and Vanessa Williamson. 2018. From the Bargaining Table to the Ballot Box: Political Effects of Right to Work Laws. Cambridge, MA: National Bureau of Economic Research. http://www.nber.org/papers/w24259.pdf (April 14, 2018). 
Ferris, Sarah, Heather Caygle, and John Bresnahan. 2020. "House Passes Sweeping Police Reform Bill." POLITICO. https://www.politico.com/news/2020/06/25/police-reform-planhouse-339691 (July 8, 2020).

Fertig, Natalie. 2020. "Cory Gardner's Marijuana Problem." POLITICO. https://www.politico.com/news/2020/05/23/cory-gardners-marijuana-problem-275029 (July 7, 2020).

Finger, Leslie K., and Michael T. Hartney. 2019. "Financial Solidarity: The Future of Unions in the Post-Janus Era." Perspectives on Politics: 1-17.

Fossil Fuel Subsidies: A Closer Look at Tax Breaks and Societal Costs. 2019. Environmental and Energy Study Institute.

Frank, John. 2018. “It Wasn't Just Cash: How Texting Cannabis Voters and Tech Outreach Strategies Lifted Jared Polis to Victory." The Colorado Sun.

https://coloradosun.com/2018/11/08/how-jared-polis-won/ (February 2, 2021).

Franko, William W., and Christopher Witko. 2018. The New Economic Populism: How States Respond to Economic Inequality. Oxford University Press.

Gramlich, John. 2020. "Four in Ten U.S. Drug Arrests in 2018 Were for Marijuana Offenses Mostly Possession." Pew Research Center. https://www.pewresearch.org/facttank/2020/01/22/four-in-ten-u-s-drug-arrests-in-2018-were-for-marijuana-offensesmostly-possession/ (June 30, 2020).

Grodzins, Morton, ed. 1982. American System: A New View of Government in the United States. 1 edition. New Brunswick N.J., U.S.A: Routledge.

Grumbach, Jacob M. 2018. "From Backwaters to Major Policymakers: Policy Polarization in the States, 1970-2014." Perspectives on Politics 16(2): 416-35.

Hacker, Jacob S. 2002. The Divided Welfare State: The Battle over Public and Private Social Benefits in the United States. Cambridge: Cambridge University Press. https://www.cambridge.org/core/books/divided-welfarestate/A03D80F34E7A6764677E794038A7CB89 (October 28, 2020).

Hacker, Jacob S., and Paul Pierson. 2014. "After the 'Master Theory': Downs, Schattschneider, and the Rebirth of Policy-Focused Analysis." Perspectives on Politics 12(3): 643-62.

Hall, Richard L., and Frank W. Wayman. 1990. "Buying Time: Moneyed Interests and the Mobilization of Bias in Congressional Committees." American Political Science Review 84(3): 797-820.

Healy, Andrew, and Neil Malhotra. 2013. "Retrospective Voting Reconsidered." Annual Review of Political Science 16(1): 285-306. 
Herndon, Astead W. 2018. “Meet Colorado's New Single-Issue Voters: The Cannabis Community." The New York Times.

https://www.nytimes.com/2018/06/25/us/politics/colorado-cannabis-governor.html (July 7, 2020).

Hertel-Fernandez, Alexander. 2016. "How Employers Recruit Their Workers into PoliticsAnd Why Political Scientists Should Care." Perspectives on Politics 14(2): 410-21.

Hertel-Fernandez, Alexander, Matto Mildenberger, and Leah C. Stokes. 2019. "Legislative Staff and Representation in Congress." American Political Science Review 113(1): 1-18.

Higdon, James. 2019. "Why 2019 Could Be Marijuana's Biggest Year Yet.” POLITICO Magazine. https://politi.co/2FPaXko (May 26, 2020).

How Do Marijuana Taxes Work? 2020. Tax Policy Center, Urban Institute and Brookings Institution. https://www.taxpolicycenter.org/briefing-book/how-do-marijuana-taxeswork (February 2, 2021).

Kalla, Joshua L., and David E. Broockman. 2016. "Campaign Contributions Facilitate Access to Congressional Officials: A Randomized Field Experiment." American Journal of Political Science 60(3): 545-58.

Karch, Andrew, and Shanna Rose. 2019. Responsive States: Federalism and American Public Policy. Cambridge: Cambridge University Press. https://www.cambridge.org/core/books/responsivestates/24A861C792C2A8B3B66C222E527103F5 (December 4, 2020).

Lax, Jeffrey R., and Justin H. Phillips. 2012. "The Democratic Deficit in the States." American Journal of Political Science 56(1): 148-66.

Lee, Frances. 2009. Beyond Ideology. University of Chicago Press. https://www.press.uchicago.edu/ucp/books/book/chicago/B/bo8158910.html (December 4, 2019).

Lindblom, Charles Edward. 1977. Politics and Markets: The World's Political Economic Systems. Basic Books.

Mayhew, David R. 1974. Congress: The Electoral Connection. New Haven: Yale University Press.

Meckling, Jonas, and Samuel Trachtman. 2021. "The Home State Effect on National Business Coalitions: Evidence from U.S. Climate Politics."

https://preprints.apsanet.org/engage/apsa/article-details/60022e995152fc0018aa565b (January 21, 2021).

Medical \& Recreational Marijuana Growing Industry in the US. 2019. IBISWorld. https://www.ibisworld.com/default.aspx (February 1, 2021). 
Metcalf, Gilbert E. 2019. On the Economics of a Carbon Tax for the U.S. Brookings. https://www.brookings.edu/wp-content/uploads/2019/03/On-the-Economics-of-aCarbon-Tax-for-the-United-States.pdf.

Mettler, Suzanne. 2014. Degrees of Inequality: How the Politics of Higher Education Sabotaged the American Dream. Illustrated Edition. New York: Basic Books.

Michener, Jamila. 2018. Fragmented Democracy. Cambridge University Press.

Moe, Terry. 2011. Special Interest: Teachers Unions and America's Public Schools. 1st edition, edition. Brookings Institution Press.

Moe, Terry M. 2015. "Vested Interests and Political Institutions.” Political Science Quarterly 130(2): 277-318.

Murphy, Kevin. 2019. “Cannabis Is Becoming A Huge Job Creator.” Forbes.

https://www.forbes.com/sites/kevinmurphy/2019/05/20/cannabis-is-becoming-a-hugejob-creator/ (June 30, 2020).

Newell, Jim. 2020. “Police Reform Is Popular Now.” Slate Magazine. https://slate.com/news-and-politics/2020/06/police-reform-is-popular-now.html (July 8, 2020).

Patashnik, Eric M. 2008. Reforms at Risk: What Happens After Major Policy Changes Are Enacted. Princeton: Princeton University Press.

Perlmutter, Ed. 2019. (U.S. House of Representatives) Secure And Fair Enforcement Banking Act of 2019. https://www.congress.gov/bill/116th-congress/house-bill/1595/text (June 30,2020 ).

Pierson, Paul. 1993. "When Effect Becomes Cause: Policy Feedback and Political Change." World Politics 45(4): 595-628.

-_- 1994. Dismantling the Welfare State?: Reagan, Thatcher and the Politics of Retrenchment. Cambridge: Cambridge University Press.

Poole, Keith T., and R. Steven Daniels. 1985. "Ideology, Party, and Voting in the U.S. Congress, 1959-1980." American Political Science Review 79(2): 373-99.

Rabe, Barry G. 2004. Statehouse and Greenhouse: The Emerging Politics of American Climate Change Policy. Brookings Institution Press.

Skocpol, Theda. 1992. Protecting Soldiers and Mothers. Cambridge, MA: Harvard University Press. https://www.jstor.org/stable/j.ctvjz81v6 (January 20, 2021).

_- - 2013. "Naming the Problem: What It Will Take to Counter Extremism and Engage Americans in the Fight against Global Warming." : 145.

Stokes, Leah. 2020. Short Circuiting Policy: Interest Groups and the Battle Over Clean Energy and Climate Policy in the American States. New York, NY: Oxford University Press. 
The War on Marijuana in Black and White. 2013. New York, NY: American Civil Liberties Union.

Trachtman, Samuel. 2020. "Policy Feedback and Interdependece in American Federalism: Evidence from Rooftop Solar Politics." Presented at 2019 APSA annual meeting. Working Paper. https://drive.google.com/file/d/1HsvRRd9xr4WSWu4R7VSOP5WEPeooaAar/view.

"U.S. Legal Cannabis Market Growth." 2019. New Frontier Data. https://newfrontierdata.com/cannabis-insights/u-s-legal-cannabis-market-growth/ (June $30,2020)$.

Weed, Julie. 2020. “Cannabis Industry: 2020 Predictions." Forbes. https://www.forbes.com/sites/forbestreptalks/2020/01/26/cannabis-industry-2020predictions/ (February 1, 2021).

Xu, Yiqing. 2017. "Generalized Synthetic Control Method: Causal Inference with Interactive Fixed Effects Models." Political Analysis 25(1): 57-76. 


\section{State Policy and National Representation: Marijuana Politics in American}

Federalism

\section{Appendix}

Samuel Trachtman, UC Berkeley

\section{A.1 Descriptive information}

Figure A1: Citizen initiative rules

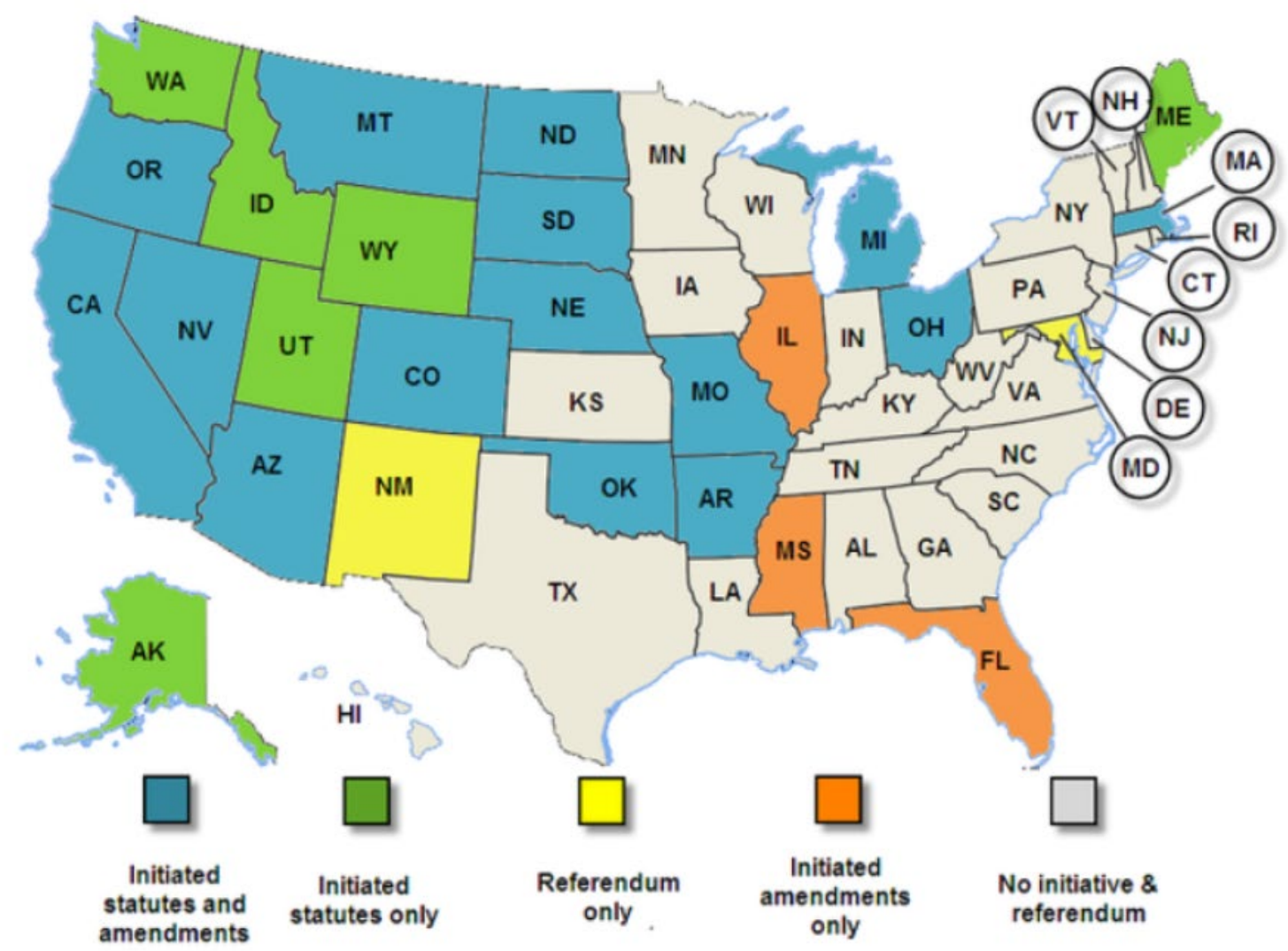

Source: Ballotpedia 
Figure A2: Bill sponsorship score distributions by legalization status

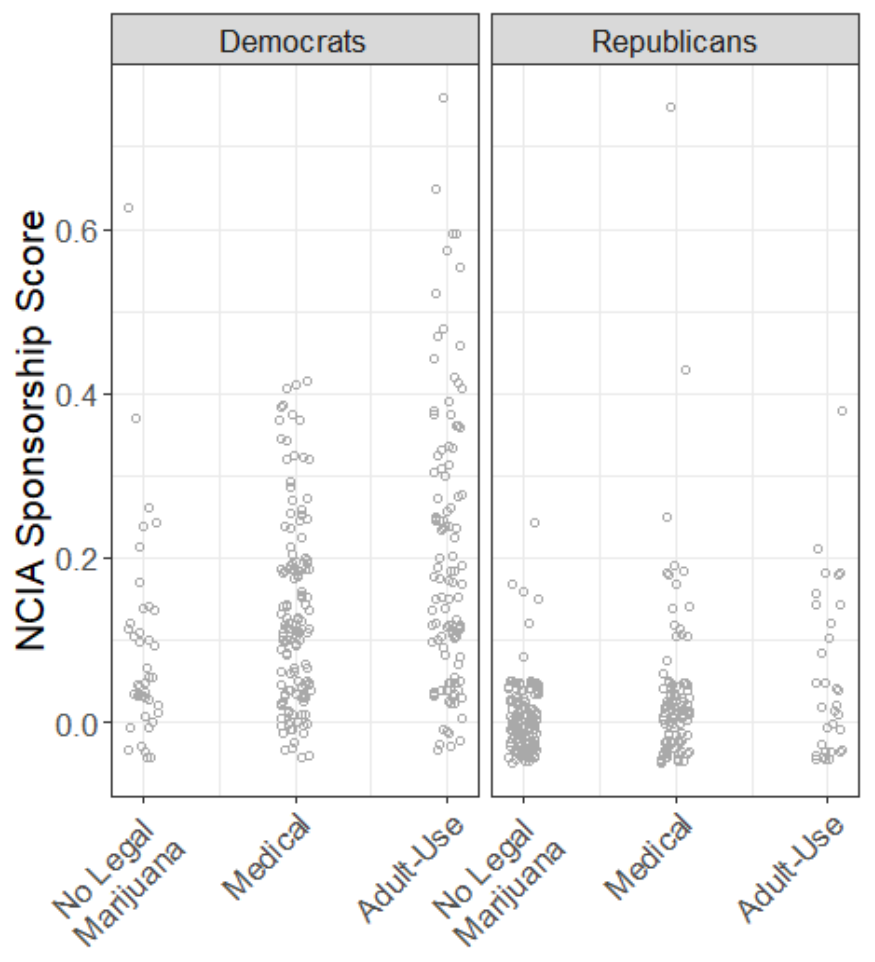




\section{A.2 Robustness checks and additional analyses}

Table A1: First stage regression results

Marijuana legalization status

(1)

Ballot initiative

$0.98^{* * *}$

$0.87^{* * *}$

Democratic PID

DW-NOMINATE dimension 1 $-0.04$

DW-NOMINATE dimension2

$(0.35)$

Social liberalism 2000s

$$
0.40^{* * *}
$$

$(0.07)$

Observations 544 542

F Statistic $396.99^{* * *}(\mathrm{df}=1 ; 542)$

Note: ${ }^{* *} \mathrm{p}<0.01$

Figure A3: Effects of state marijuana legalization on bill sponsorship in the 116th Congress, excluding western states. ${ }^{18}$ Figure presents estimates from two-stage least squares

18 These include: AZ, CO, ID, NM, MT, UT, NV, WY, AK, CA, HI, OR, WA. 
regression. State legalization status is instrumented by citizen initiatives rules. 95 percent confidence intervals are calculated using standard errors clustered at the state-level.



Figure A4: Effects of state marijuana legalization on bill sponsorship in the 116th Congress, alternative legalization status coding. Figure presents estimates from two-stage least squares regression. State legalization status is instrumented by citizen initiatives rules. 95 percent confidence intervals are calculated using standard errors clustered at the state-level. In 
this specification, states with legalized adult-use marijuana are coded as "treated", with medicaluse and prohibition states in the control group.

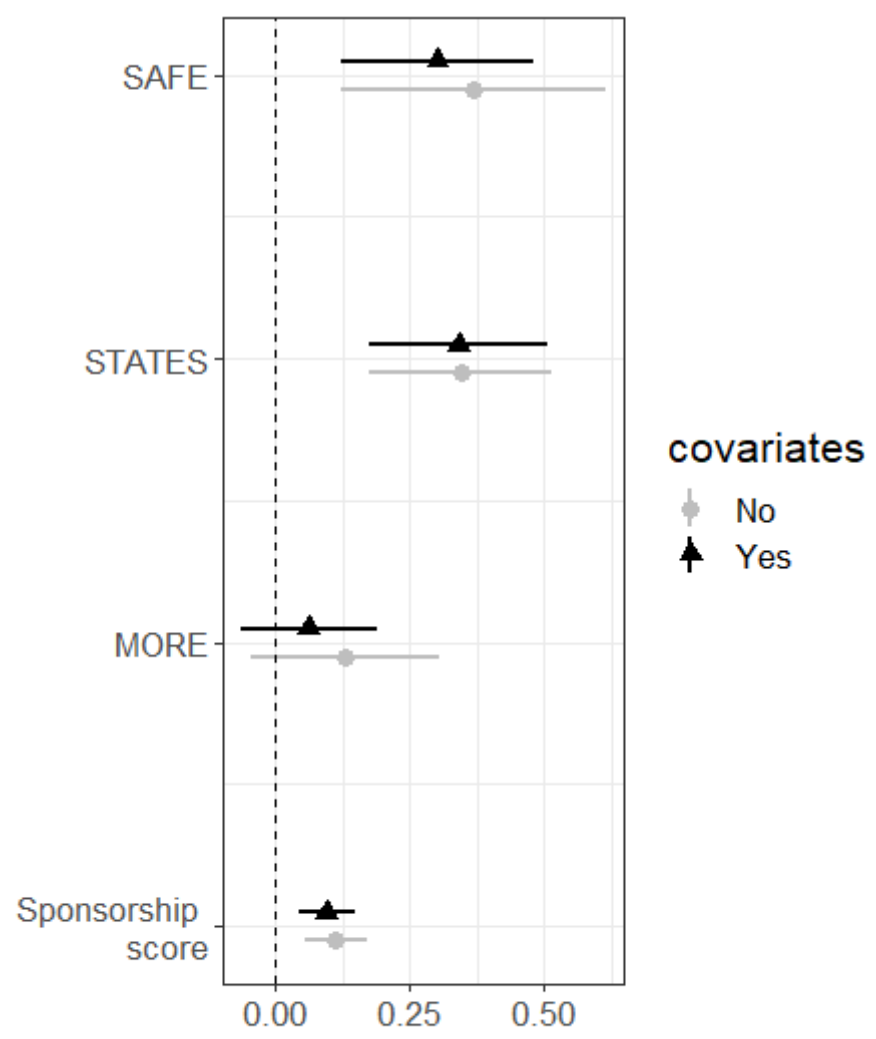

Figure A5: Effects of state marijuana legalization on bill sponsorship in the 116th

Congress, by party. Figure presents estimates from two-stage least squares regression. State legalization status is instrumented by citizen initiatives rules. 95 percent confidence intervals are calculated using standard errors clustered at the state-level. 


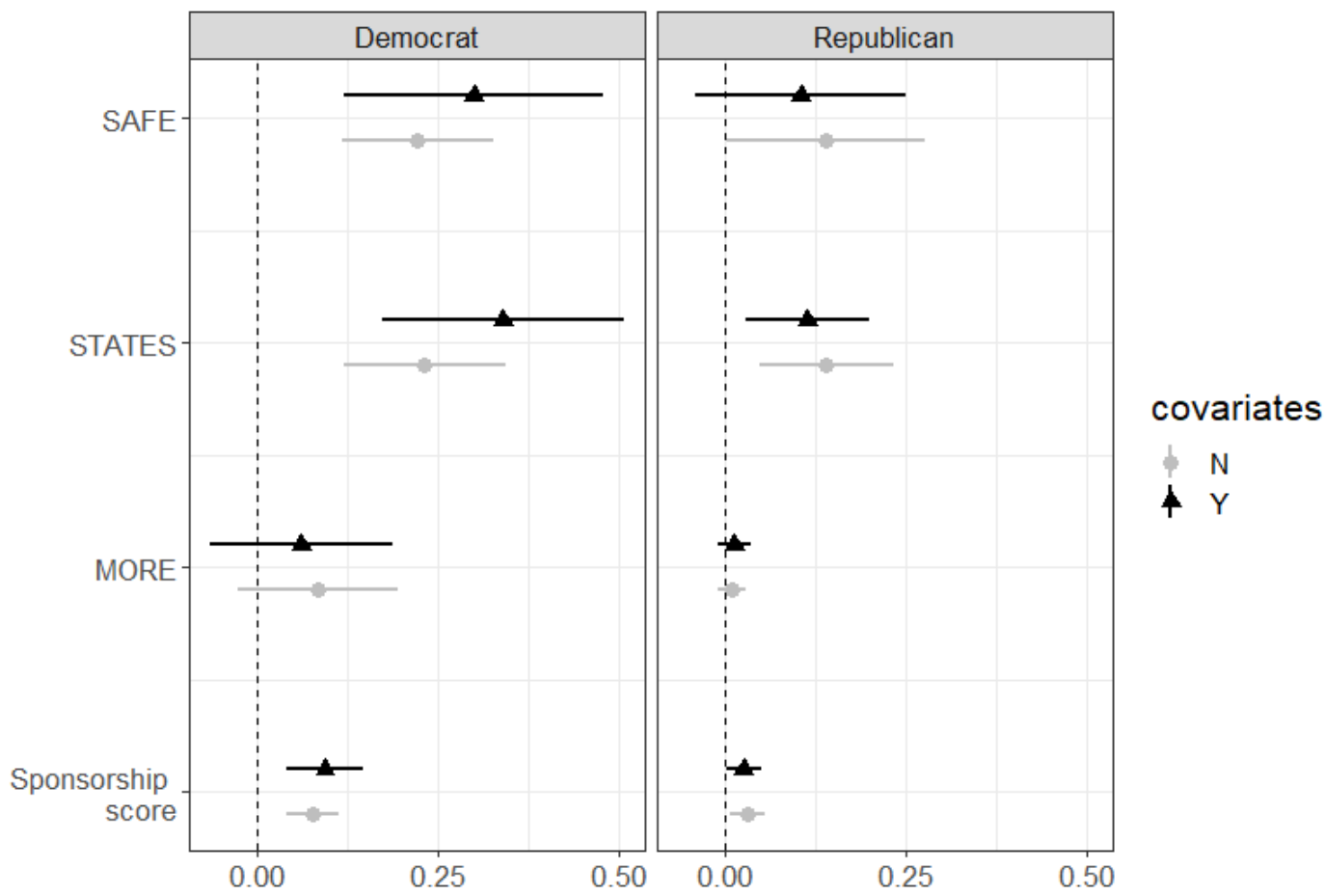

Figure A6: Effects of state marijuana legalization on bill sponsorship in the 116th

Congress, covariate adjustment specification. Covariates include party identification, ideology (DW-NOMINATE first and second dimensions), 2016 presidential vote (state-level), and social liberalism (state-level). 


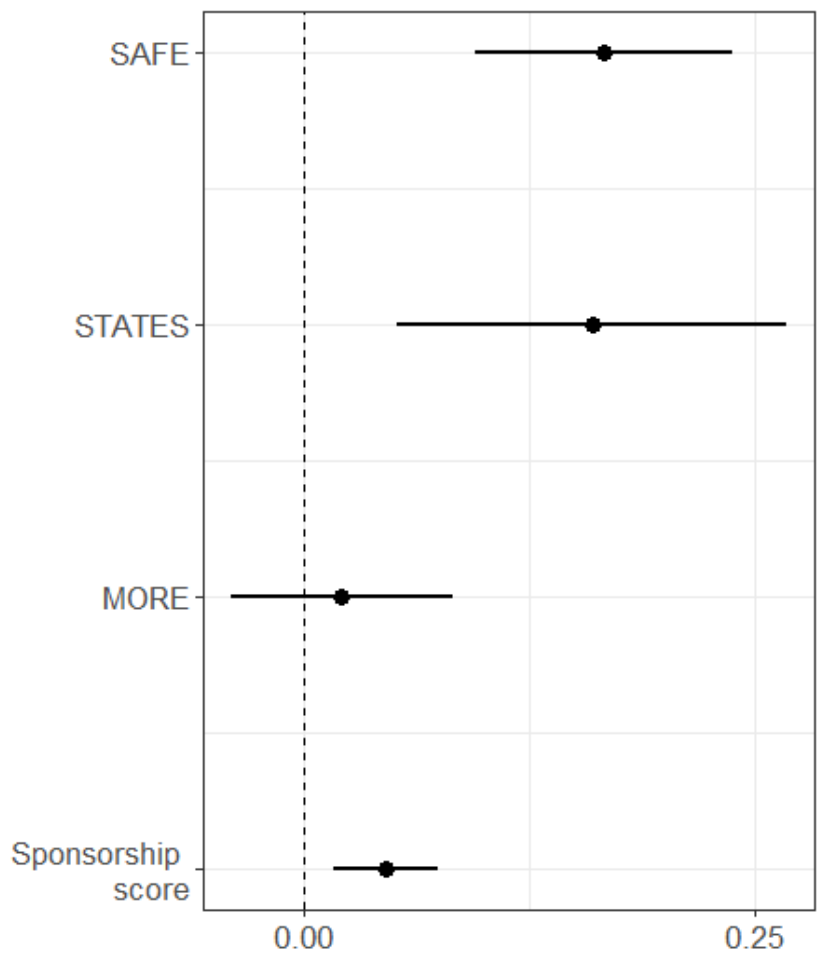

Figure A7: Effects of state marijuana legalization on roll-call voting in the 116th Congress, covariate adjustment specification. Covariates include party identification, ideology (DWNOMINATE first and second dimensions), 2016 presidential vote (state-level), and social liberalism (state-level). 


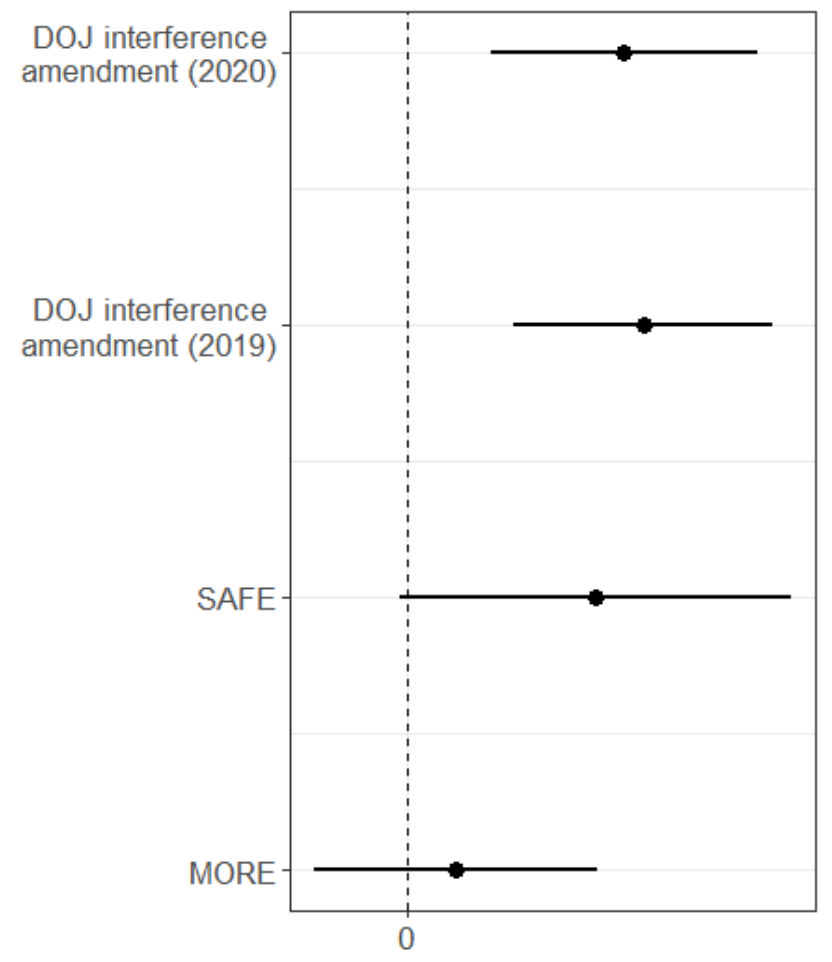

\section{A.3 Evidence on mechanisms}

Figure A8: Proportion of 2018 congressional elections with marijuana industry contributions by legalization status 


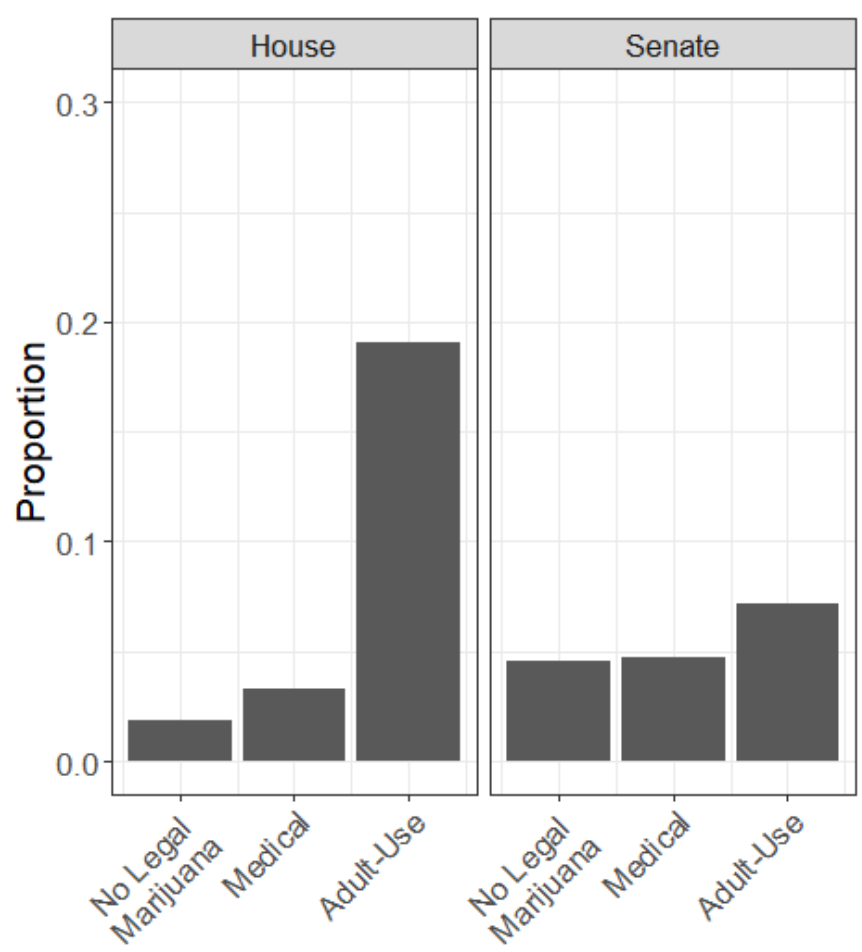

Figure A9: Effect of legalization on receiving campaign donations from marijuana industry in 2018 election cycle. Figure presents estimates from two-stage least squares regression. Outcome is a binary indicator for receiving contributions from marijuana industry. State 
legalization status is instrumented by citizen initiatives rules. 95 percent confidence intervals are calculated using standard errors clustered at the state-level.

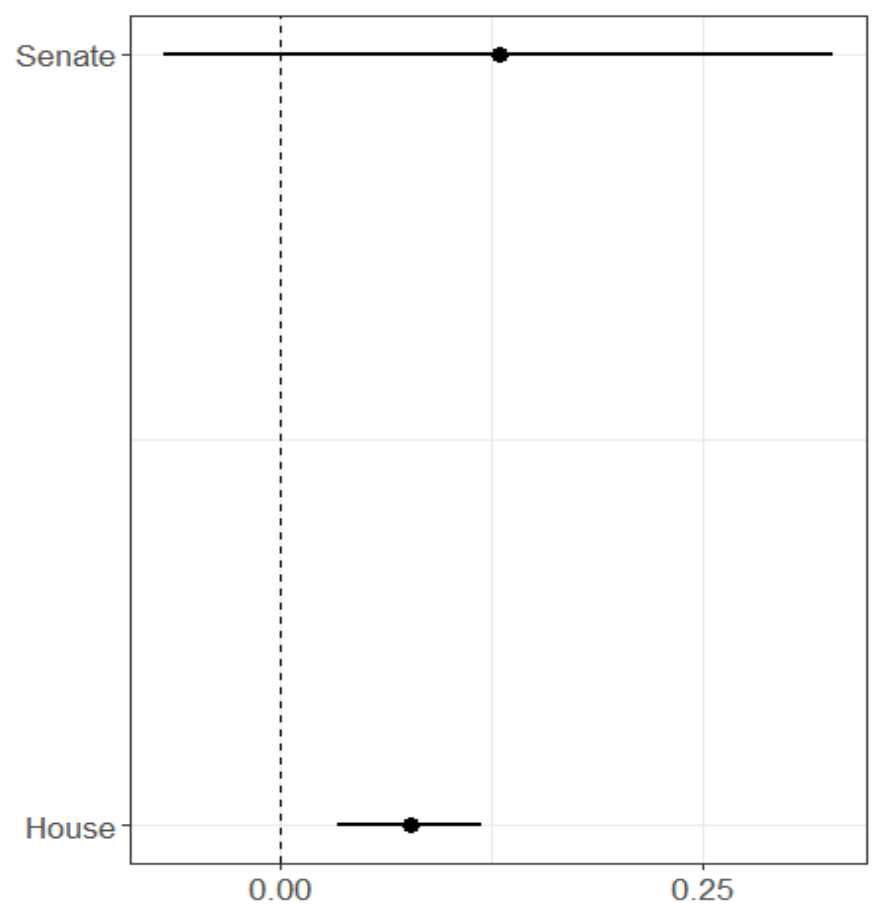

\section{A.4 Ethics in social science research}

This research drew in part on semi-structured interviews with individuals with subject matter expertise. The research was exempted from IRB approval because these individuals were asked about matters directly relevant to their own work. Voluntary consent was obtained through both phone and follow-up email. 